\title{
Servitization and advanced business services as levers for competitiveness
}

\author{
Bart Kamp $^{a}$ \\ Glenn Parry ${ }^{b}$ \\ a Orkestra-Fundación Deusto, Kalea Mundaiz 50, E-20012, Donostia/San Sebastian (Spain), Deusto \\ Business School, Universidad de Deusto, Av. de las Universidades, 24, E-48007, Bilbao (Spain) and . \\ Louvain School of Management, Université Catholique Louvain-la-Neuve, Centre des PMEs, 1, Place \\ de l'Université, B-1348 Louvain-la-Neuve (Belgium). \\ e-mail: bart.kamp@orkestra.deusto.es \\ ${ }^{\mathrm{b}}$ Department of Strategy and Operations Management, Faculty of Business and Law, UWE, Bristol, \\ BS16 1QY, UK
}

\section{1-Introduction}

Vandermerwe and Rada (1988) recognized that many firms were seeking to improve competitiveness and turnover by increasing the service offer of their portfolio. The term they employed for the change process they observed is "Servitization" and they stated that it occurs when companies consciously develop their businesses "into" services to add value. Servitization has since been described in a number of ways depending on the authors' theoretical lens and context of study, including: as a change in management philosophy where service is re-evaluated as an integral part of the supply transaction with importance before and after the moment of object supply (De Toni et al., 1994); as the ability to differentiate through supplier/customer relationships, providing an escape from product providers' cost leadership strategies (Robinson et al., 2002); as the innovation of an organization's capabilities and processes to better create mutual value through a shift from selling product to selling Product-Service Systems (Neely et al., 2008); and as the move by manufacturing companies towards offering goods and services rather than goods alone (Baines et al., 2009). The common intent behind servitization strategies, therefore, seems to be: "firms seeking to enhance their competitive position by focussing attention on service provision".

In that regard; Oliva and Kallenberg, begin their 2003 paper by noting that management literature "is almost unanimous in suggesting to product manufacturers that they should integrate services into their core product offerings". They identify strong arguments for service adoption; revenue generation from an installed product base; stable revenue streams from service contract payments; potential for higher margins; competitive advantage as services are difficult to imitate. 
Service applications are often studied within business-to-consumer settings. In contrast servitization is a concept that is founded and primarily studied within the context of industrial networks and business-to-business relationships, hence the relevance of product-service transitions to Industrial Marketing Management's readership. Hakansson and Shehota (1995), Gadde, Hümer and Hakansson (2003) and Hakansson et al. (2009) suggest that B2B exchange processes can be interpreted as a configuration of individual activities of companies that are embedded into wider activity patterns across the boundaries of individual firms. That is to say, as parts of a longer value chain that builds upon interdependent activities, as well as cooperation and exchange processes (Hedvall et al., 2016). By looking at servitization from a relational perspective, scholars frame servitization as a way to conceive changes in inter-firm relationships (Penttinen and Palmer, 2007; Kindström and Kowalkowski, 2009), where users and producers work together in partnership and move towards long-term cooperation (Hakansson, 1993; Kamp, 2005). Servitization therefore challenges the confrontational leverage position that firms can adopt within markets where arm's length relationships prevail (Williamson, 1975, 1985), in line with Johanson and Mattsson's (1987) paper on inter-organizational relations in industrial systems. They argue that recurring interactions between businesses create inter-dependencies, dynamics of adaptation and bonding effects. Hence, they posit that inter-firm exchanges contribute to B2B stability and partnership. ${ }^{1}$ This supports the hypothesis that servitization strengthens ties and underpins long term cooperative relationships between users and producers, creating space to support the client in value creation processes (Mathieu, 2001) and for risk-reward sharing (Allmendinger and Lombreglia, 2005; Randall et al., 2010; Baines and Lightfoot, 2014). Consequently, servitization fosters understanding and appreciation of value-in-use for customers (MacDonald et al., 2011) and can ultimately lead to "mutuality" (Anderson, Hakansson and Johanson, 1994), or as phrased by Jaakkola and Hakanen (2013, p. 49): “As interaction between companies develops, their resources become mutually adapted, i.e. resource ties emerge". In a similar vein, interactive service relationships are often linked to recurrent revenue streams and may lead to payment model innovations, for example by proposing pay-per-use schemes instead of one-shot sales transactions (e.g. Tukker, 2004).

Given the potential benefits promised to firms by servitization and the multifaceted character of the concept, it is perhaps unsurprising that a significant body of work has been developed. In searches on leading databases we now find over 500 papers referring directly to servitization. However, this underestimates the total body of work available in relation to servitization as there are some very

\footnotetext{
1 “... an interfirm relationship is a mutual orientation of two firms toward each other. This implies that the firms are prepared to interact with each other and expect each other to do so." (Johanson and Mattsson, 1987, p. 37).
} 
closely aligned research communities (notably from the production engineering and IT realm) that refer to servitization-related concepts without using the term itself.

In the servitization section of IMM's special issue Vol 60/2017, we examine the current state of the domain of servitization and provide insight into emerging trends. The opening paper by Brax et al., can be viewed as a mapping exercise that structures the field and provides an inventory of the published articles on servitization. Brax et al. identified a number of closely related terms including service infusion, service addition, service transition, integrated solution and product service system. Scholars who deploy these terms likewise contribute to understanding of the pursuit of value through service. The following article, by Story et al., reports on and conceptualizes contemporary servitization practices from an empirical/field-level perspective. The article by Gemser et al. also takes an empirical perspective on contemporary servitization questions, this time from a more practitioner-orientated perspective. The articles of Coreynen et al. and Vendrell et al. fulfil a double objective. First, they provide insight into contemporary issues in servitization. Second, they support the forward-looking mission of the section by providing an insight into new developments in the field, in particular with regard to the enabling power of new technologies such as digitalization and advanced manufacturing.

This paper is structured as follows. In section 2 we provide a digest of the articles that contribute towards the special issue section on servitization, summarising the key highlights and contributions. Following this, in section 3 we provide an outlook and discuss the need for further study of the converging paths of servitization, smart products and processes enabled by the uptake of advanced manufacturing technologies/Industrial Internet. In our view, this is not only a promising field for researchers from the industrial marketing realm, but also from the field of industrial production and engineering. Hence, we postulate that multi-disciplinary research projects in which scholars with backgrounds from business, computer sciences and engineering, should provide a basis for further insight to the intersection between servitization and product(ion) engineering.

\section{2- Review of contributions}

\section{1-A meta-model of servitization}

Numerous authors have attempted to create models that capture and explain the servitization process, each providing slightly different insights into the process. There is always a danger of creating 'another model', but in their work "Meta-model of servitization: The integrative profiling approach" Brax and Vistin provide a framework within which they have integrated the many servitization models and their constituent building blocks such that they can be described and 
understood. A study of the configurative richness and layers with which models can be conceived for the process of servitization is developed. The meta-model of servitization Brax and Visintin present is grounded in a systematic review of literature where servitization models (or parts thereof) are operationalized (Denyer and Tranfield, 2006). Ninety-four different models of servitization were found and treated as data points to map components and stages of servitization to develop a conceptual meta-model. By looking into the complexity of servitization, the paper shows that assessing servitization is more than looking at turnover from service indices. Consequently, by detecting patterns among these components the paper suggests eight value constellation profiles that differ in terms of degree and complexity of servitization. The authors categorize models of servitization according to three different approaches found in the literature; end-state models, gradual transition models, and step-wise progression models. As such, the paper provides a baseline to compare servitization practices along a PSS life cycle stages model.

Brax and Visintin's paper undertakes a cross-comparison of servitization models and visualizes the key differences between the value constellations that underpin them. The analysis and outcomes provided serve as a tool for organizing empirical data and interpreting the degree of servitization of firms and industry sectors. Managers may find the meta-model useful as it allows them to synoptically represent their company's offering and value proposition. This can help communicate the firms offering to customers and other relevant actors. The framework may also provide guidance in the identification of possible gaps in a firm's portfolio or in the market. Furthermore, the metamodel can facilitate the benchmarking or comparison of different offerings within and across industries. As such, it can fulfill a complementary function to a business model canvas or a balanced score card.

The paper's process and the stages of servitization allow a comparison to be made between the servitization journey of a firm with organizational change trajectories (Oliva and Kallenberg, 2003; Gebauer and Friedli, 2005). The meta-model contributes to the arguments of Finne et al. (2013) and Kowalkowski et al. (2015) who propose that servitization is not necessarily deterministic and forward-directed, but rather is a process that may also contain reverse pathways.

\section{2-Digital technologies enabling servitization}

In the emerging digital age of the Industrial Internet and Industry 4.0 concepts, digital technology and data processing become increasingly integrated with, and shaped by, B2B relationships, which in turn influence servitization practices (Kamp et al., 2016). Scholars argue that digitalization of assets and data exchange between industrial buyers and suppliers facilitates 'smart servitization' (Penttinen et al., 2007; Huang et al., 2007). Using technology to make assets smart and connected 
allows them to provide new functionalities, capture and present insightful data, and from this providers may develop stronger bonds with users (Porter and Heppelmann, 2014). Technology allows firms to look "beyond the voice of the customer" and users' stated requirements. Technology can provide visibility to the use of resources within customer-specific contexts (Parry et al., 2016). Through the analysis of data obtained from products that are endowed with sensors, providers of PSS can gain an improved understanding of the use of their offering by their clients. Two papers in this servitization section address this kind of issues of smart servitization in the era of digital technologies.

The first contribution in this regard comes from Coreynen, Matthyssen and Van Bockhaven: "Boosting servitization through digitization: Pathways and dynamic resource configurations for manufacturers". In their work, they employ Hsu's (2007) definition of digitization as the use of technologies to connect people, systems companies, products and services. Their paper examines how digitization can enable servitization for manufacturers and how firms can employ digital technologies to pursue different pathways in their servitization journey. The work also examines dynamic resource configurations, how digitization options influence the resource bases and capabilities available to servitizing firms, and how the three different servitization pathways they describe call for the deployment of different digitization regimes. The work employs a multiple casebased approach using in-depth interviews and workshops to capture primary data that describe the digital methods developed by firms in order to offer higher value-added services that support customer processes. Each company case provides illustrations of how three different pathways are followed in practice.

Against this backdrop, the authors create a framework building upon the work of Storbacka (2011) who proposes a dyad of industrial and commercial operational perspectives. Industrial operations pertain to 'back-end' firm activities that lead to improvement in efficiency and effectiveness in creating solutions. The commercial perspective relates to gaining an understanding of customers' value creating processes. Coreynen et al. propose a third pathway they name 'value servitization' that recognizes firms are creating digitally enabled offerings that can disrupt current practice and radically change provider-customer relations. In summary: The Industrial Servitization Pathway uses digital technologies, resources and capabilities to make internal manufacturing operations smarter and translate this internal optimization into new hybrid services and added value for clients (Ulaga and Reinartz, 2011; Kindström and Kowalkowski, 2014). However, it represents an internal trajectory for a firm, without significant integration of the client's value chain with that of the supplier; The Commercial Servitization Pathway aligns internal value creation processes with those of customers 
and suppliers. It provides for greater interaction among buyers and suppliers, and thus requires the development of customer support capabilities. Consequently, the digital technologies that are relevant for this pathway go beyond the realm of production and have to support intelligence gathering and semantics to capture customer needs (Parida et al., 2014). An important resource -or contingency- to allow for such data exchange and insight gathering is working in partnership with customer approval and involvement (Kindström and Kowalkowski, 2014); The Value Servitization Pathway takes inter-organizational value creation alignment to a higher level as it requires manufacturers to further integrate with the value generation processes of the customer. While value servitization embodies elements from the previous two pathways, distinct features of this approach are its boundary-spanning nature (Day, 1994) and its result-oriented character. Consequently, value servitization requires capabilities and resources that allow customers to monitor product usage and performance to achieve particular outcomes (Ulaga and Reinartz, 2011; Kindström and Kowalkoski, 2014).

The second contribution to digital servitization comes from Vendrell-Herrero, Bustinza, Parry and Georgantzis who look at the implications from the perspective of bargaining power between buyers and suppliers. In their paper "Servitization, digitization and supply chain interdependency" VendrellHerrero et al. examine power interdependencies that can arise during servitization. The work gives insight into changes in the balance of power between actors in a supply chain that can impact on the value capture ability of firms implementing servitization strategies.

Digital products often form a substitute for traditional offerings (Greenstein, 2010), and this form of servitization has previously been classified as a Result-oriented Product Service System (Tukker, 2004; Neely et al., 2008). Accordingly, Vendrell-Herrero et al. examine the dematerialization of physical objects within the context of the book publishing industry - the substitution of physical books with digital books - which they describe in terms of digital servitization (Holmström and Partanen, 2014; Schroeder and Kotlarsky, 2015). In the book publishing industry, disagreements over price have been observed between book publishers and retailers (Baye, De los Santos and Wildenbeest, 2013). The paper links the analysis of such disagreements to power and the ability that buyers and suppliers have to appropriate value within exchange relationships (Cox, 1999; Scheer et al., 2014).

The work uses survey data from 8000 consumers in the UK and USA and employs the payment card method (Camacho-Cuenca et al., 2004) to determine the consumers' willingness to pay for e-books, using physical books as an anchor for pricing. Average market prices are used to test if price set is above or below the revenue maximizing price. The analysis shows that e-retailers give significant 
price discounts on books that are out of copyright in order to attract trade and maximize revenues. Analysis empirically validates the proposition that the provision of digital service increases the dependence of upstream suppliers on the downstream retailers. However, copyrighted e-books are found to be listed at the higher profit maximizing price point. Where upstream firms have unique resources, such as books that are within copyright, they have power in the relationship and are able to reduce their dependence on downstream firms. This supports research findings that demonstrate how unique resources can improve value capture processes in the supply chain (Costa et al., 2013; Finne et al., 2015)

Much of the servitization literature focuses upon manufacturing firms going downstream in search of revenue. Vendrell-Herrero et al. provide quantitative analysis supporting research that highlights risks associated with servitization, in particular the risk that a firm's power and ability to capture value can be reduced (Kowalkowski et al., 2015). The work suggests that the potential loss of power and hence revenue could be a reason to de-servitize.

\section{3-Network and interaction-based capabilities}

The fourth paper fits in with the tradition of approaching servitization as the process through which a company develops the capacities to provide services and solutions to customers (Neely et al., 2011; Baines et al., 2009). In their paper "Capabilities for advanced services: A multi-actor perspective", Story, Raddats, Burton, Zolkiewski and Baines examine the capabilities that come into play in the pursuit of advanced services from the perspective of manufacturers, intermediaries and customers. The work identifies which capabilities and roles are played by each of the actors within a manufacturer's downstream network for the provision of advanced services. Findings suggest that certain capabilities may have to be developed by customers (Spring and Araujo, 2014) in order for advanced services to be effective and create value. This is a distinct way through which servitization can be seen as a reciprocal process, where value is co-created through close and aligned buyersupplier interactions (Vargo and Lusch, 2008, 2011; Bastl et al., 2012).

Advanced services tend to be knowledge-intensive (Kamp et al., 2016), and the authors contend that they require manufacturers to develop their customer relationship skills in order to foster sufficient understanding of their customers' business activities and how their service offerings support the customers' core activities (Mathieu, 2001). Story et al. argue that as advanced services are dynamic in character, necessarily adapting to changing circumstances and needs, their roll-out and uptake may require a flexible stance, both from the supplier's side and also from the other actors who have controll over resources that are used in the value creating process. The latter has also been argued by Tuli et al. (2007) and Ng, Parry, Maull and McFarlane (2011). 
Story et al. also note that the required assets and capabilities for advanced services held by agents along the supply chain may be complementary or competing. There is an inherent challenge to integrate with partners whilst identifying and maintaining a distinct capability to protect a market position. Their finding reflects that of the work of Vendrell-Herrero et al. who found that firms need unique resources to maintain power, as the intermediaries' ability to maintain a distinctive competence will help them to build their position in the network by developing their capabilities and thus avoid 'value slippage', whereby they give up value to other network actors (Lepak, Smith, and Taylor, 2007; Parry and Tasker, 2014). The authors propose that servitizing manufacturers' need to think holistically about who to work with and how to cooperate in order to manage the "coopetitive" tensions that may arise (Bengtsson and Kock, 2014). The authors propose that actors seeking to develop advanced services require key capabilities that include the ability to know what to outsource. Complementary capabilities are required in their customers, with absorptive capacities, lead user traits and process re-engineering skills required if the provider is to find fertile ground in the user organization and for that customer to engage in the process of service innovation.

The findings from their field work from nineteen UK-based companies leads to the formulation of a series of propositions for 'what are the unique and critical capabilities of each actor in view of fostering advanced services?' For manufacturers, these are: striking the right balance between product and service innovation; developing methods to provide customer-focused through-life services; and developing distinct -yet synergistic- product and service cultures inside the firm. For intermediaries, the ability to coordinate and integrate third party products/services is highlighted. For customers, the authors point to the ability to co-create innovation with supply side parties, and capabilities to deal with make-or-buy and sourcing processes.

\section{4-Value of Product-Service Systems}

Building upon Story et al.'s finding that customers "are only likely to want [advanced] services if they offer clear benefits over what can be provided in-house.", Kuijken, Gemser, and Wijnberg contend that customer value must have primacy in the creation of a product service system [PPS]. In their paper "Effective product-service systems: A value-based framework", Kuijken et al., propose that servitization creates PSS and for these to provide customer perceived added value, the total value of the product service systems should be greater than the sum of the parts. Manufacturers are already struggling with the marketing of PSS (see e.g. Ulaga and Loveland, 2014; Reim, Parida and Örtqvist, 2015) and this is further hindered if the value perception of customers further acts to block successful commercialization and market acceptance. 
The paper proposes a framework to analyze how PSS offerings create value as perceived by the customer, and illustrates how this framework can contribute to developing effective PSS that create sustainable value for manufacturers considering servitization. The work seeks to help companies overcome the servitization paradox, where the promised value of adding service is never realized in practice (Gebauer et al., 2005), and to provide a further operationalization of the concept of valuein-use from a customer's perspective (Vargo and Lusch, 2008).

The value-based PSS framework the authors introduce proposes that product and service constituents of a PSS should offer 'autonomous' value to the customers. Subsequently, the combination of the product and service elements are 'super-additive' or synergetic, rather than additive or sub-additive (Shankar et al., 2007). The dimensions of the $2 \times 2$ framework include the importance of the tangible aspects of the offering and the importance of customer interaction, which together are used to characterize combinations of products and services. By allocating components of a PSS across the 4 quadrants of the matrix, one can assess whether the conjoint is a super additive, additive or sub-additive whole. In order for a PSS to be super-additive it should have elements in more than one, preferably opposed, quadrants.

The results of supply side analysis suggest that the dimensions of tangibility and interaction are important independent characteristics which can be used to differentiate between products and services. In the demand side analysis it was found that the customers' perceived value of synergies between products and services was key, and if found to be insufficient, led to a lack of willingnessto-pay for the PSS. The results suggest that synergy is not easily created during servitization and so assessment of the super additive value of a PSS before offering it to the market is beneficial to firms.

The experimental basis that the paper develops can provide guidance on the industrial marketing of PSS and determine price points in accordance with customers' willingness-to-pay for value propositions. The framework that the paper provides can be employed to determine where the tipping point between accumulating and decreasing marginal utility of PSS configurations lies. The approach can serve as a point of reference in order to determine the extent with which servitization is possible, and at which point it becomes necessary to stop or reverse servitization and engage a deservitization process. The paper further provides insights to processes whereby service providers choose to offer PSS by adding products to existing services, a process known as 'productization' (Jaakola, 2011). 


\section{3-Implications and future research directions}

Servitization is an expanding field of research that is amenable to study through multiple theoretical constructs (Brax et al., 2017; Kowalkowski, Gebauer and Oliva, 2017). We observe a growing diversity regarding the way in which companies bring servitization into practice. From an industrial marketing perspective it is particularly relevant to focus on questions that build understanding of the phenomenon: (1) "how servitization might alter the value propositions of traditional manufacturing companies in B2B settings: How to shape new propositions?"; (2) "where to draw the line between user and supplier responsibilities; or will these borders become increasingly blurred/intertwined?" I.e., what is the role of the customer and what is the role of the provider? By extension: what is the role of the supplier of physical assets: should that be limited to the supply of tangible goods or go beyond that? Accordingly, in terms of make-or-buy decisions and supply chain management, salient issues are (3) "can suppliers of industrial goods become a one-stop-shop and full service/solution provider to industrial users by means of systems of products and services during the lifecycle of the goods in question?" Furthermore, (4) "to what extent will new -digital- technologies act as an intervening variable (e.g. enabler) in the shaping of servitization practices within industrial relationships?"

While questions (1), (2) and (3) have formed part of the core of servitization research to date, research that examines issues stemming from the fourth strand constitutes an incipient line of investigation. Examples of early works at the cross-roads between Industrial Internet or Industry 4.0 and servitization, include Lee, Kao and Yang (2014), Schroeder and Kotlarsky (2015), Herterich, Übernickel and Brenner (2015) and Kamp, Ochoa and Diaz (2016). The contributions of Coreynen et al (2017) and Vendrell-Herrero et al (2017) in this section add further to this body of work. We observe that scholars are becoming more deeply engaged with the challenge and benefits that digital technologies bring to servitization. Examination of presentations at recent editions of the Spring Servitization Conference and the International Conference on Business Servitization show how the share of presented papers with an Industrial Internet and B2B perspective on servitization went from a negligible share in 2013 to some $15 \%$ in 2016. This runs parallel with the uptake of Industry 4.0 practices and advanced manufacturing technologies by business. Hence, we expect that research in this area will necessarily develop further, particularly as more firms seek to adopt new technologies that foster innovative servitization practices (Ayerbe et al., 2014; PCAST, 2011, 2014), advanced services and servitized business models (Penttinen et al., 2007; Huang et al., 2007). In our view the implementation of "service-enabling technology" will not only have an impact on the shape and scope of inter-firm relationships, in the form of concepts like mutuality and interdependence (Anderson et al., 1994; Hedvall et al., 2016), and the financial governance of such relationships 
(Randall et al., 2010; Baines and Lightfoot, 2014), but it will also create new opportunities for innovation in servitization and increase the sophistication of service practice.

Implicit in the uptake of new 'digital' technologies is the establishment of connectivity between the assets and actors concerned. This can be achieved through the use of smart, connected goods, and by giving a smart and connected dimension to the relationships between the implicated buyer supplier parties. Accordingly, smart assets and actors in combination with digital connections and rapid analysis of the big real time datasets generated act as a lever for smart services (see e.g. Porter and Heppelmann, 2014). Distant monitoring allows for a better "visualization" of the state and use of assets, which provides a stepping stone for remote interventions and servicing as well as more customized services for users. In parallel, data provides a basis from which firms may move from (base) services that support goods to (advanced) services that assist clients in their own valuecreating processes. Digital technologies create the foundation for the development of a mutual orientation of users and suppliers in regard to the value creation processes that span the boundaries of individual firms. In providing a systemic understanding of value creation processes -including the way that assets provided by suppliers are deployed as part of the clients value creating processes more accurate information can be obtained on the performance of assets in-use, including data on their output, capacity or productive/idle time (Vargo and Lusch, 2004). This can provide a valuable basis for designing smart payment schemes that deviate from classic sales transactions, and take into account Lifecycle Cost of Use principles (see e.g. Allmendinger and Lombreglia, 2005). Consequently, we argue that investigating the influence of digital technologies on the course and pluriformity of servitization practices is a promising avenue for future research.

Servitization is not only an expanding field of research, it is also where the practices and actors that form the focal unit of analysis are dynamic and situated in contexts that are in a constant state of flux. Practice will likely change quickly and as a consequence scholars will have to accept that they are, in a way, dealing with moving targets. Therefore, there is a need for forward-looking studies and prospective analysis. Similarly, with the development of the Industrial Internet, novel communication technologies and big data analysis into the world of servitization, the area of research is becoming an increasingly multidisciplinary domain. Consequently, insightful research and publications will arguably require the formation of research teams with a diverse theoretical background. 


\section{References:}

Allmendinger, G., Lombreglia, R.: Four strategies for the age of smart services. Harvard Busin. Rev. 83(10), 131-145 (2005)Amit, R., and C. Zott (2001). 'Value creation in e-business', Strategic management journal, 22, pp. 493-520.

Anderson, J., Hakansson, H., and Johanson, J. (1994). Dyadic business relationships within a business network context. Journal of Marketing, 58(4), 1-15

Ayerbe, A., Cirion, I., Mansell, J., De Torres, A. Gil, G., Laka, J.: Thinking products in a different way: what is needed for product servitization, Paper presented at the 3rd International Business Servitization conference, Bilbao (19-20 November 2014)

Baines, T. S., Lightfoot, H. W., Benedettini, O., and Kay, J. M. (2009). The servitization of manufacturing: A review of literature and reflection on future challenges. Journal of Manufacturing Technology Management, 20(5), 547-567.

Baines, T., Lightfoot, H., Smart, P., Fletcher. S. (2013). Servitization of manufacture, Journal of manufacturing technology management: $24,(4): 63$

Baines, T. S., and Lightfoot, H.W. (2014). Servitization of the manufacturing firm. Exploring the operations practices and technologies that deliver advanced services. International Journal of Operations and Production Management, 34(1), 2-35.

Bastl, M., Johnson, M., Lightfoot, H., and Evans, S. (2012). Buyer-supplier relationships in a servitized environment: An examination with Cannon and Perreault's framework. International Journal of Operations and Production Management, 32(6), 650-675.

Benedettini, O., Swink, M., and Neely, A. (2015). Why do servitized firms fail? A risk-based

Baye, M. R., De los Santos, B., and Wildenbeest, M. R. (2013). Searching for physical and digital media: The evolution of platforms for finding books. NBER Working Paper No. 19519.

Benedettini, $O$ and Swink, $M$ and Neely, A (2015) Examining the influence of service additions on manufacturing firms' bankruptcy likelihood. Industrial Marketing Management. ISSN 0019-8501

Bengtsson, M., and Kock, S. (2014). Coopetition-Quo Vadis? Past accomplishments and future challenges. Industrial Marketing Management, 43, 180-188

Brax. S.A. and F. Visintin (2017). Meta-model of servitization: The integrative profiling approach, Industrial Marketing Management, This issue

Bustinza, O., Parry, G., Vendrell-Herrero, F. (2013). "Supply and Demand Chain Management orientation - Adding services to product offerings", Supply Chain Management: An International Journal, Vol. 18 (6), pp.618-629

Camacho-Cuenca, E., García-Gallego, A., Georgantzís, N., and Sabater-Grande, G. (2004). An experimental validation of hypothetical WTP for a recyclable product. Environmental and Resource Economics, 27(3), 313-335. 
Coreynen, W., Matthyssens, P. and W. Van Bockhaven (2017). Boosting servitization through digitization: Pathways and dynamic resource, configurations for manufacturers, Industrial Marketing Management.

Costa, L.A., Cool, K., Dierickx, I., 2013. The competitive implications of the deployment of unique resources. Strategic Management Journal 34 (4), 445-463.

Cox, A. (1999). Power, value and supply chain management. Supply Chain Management: An International Journal, 4(4), 167-175.

Day, G. S. (1994). The capabilities of market-driven organizations. Journal of Marketing, 58(4), 37.

De Toni, A., Nassimbeni, G., and Tonchia, S. (1994). Service Dimensions in the Buyer-Supplier Relationship: A Case Study. International Journal of Physical Distribution and Logistics Management, 24(8), 4-14

Finne, M., Turunen, T., Eloranta, V., 2015. Striving for network power: The perspective of solution integrators and suppliers. Journal of Purchasing and Supply Management 21 (1), 9-24.

Gadde, L. -E., Huemer, L., and Håkansson, H. (2003). Strategizing in industrial networks. Industrial Marketing Management, 32, 357-364.

Gebauer, H. and Friedli, T. (2005), "Behavioural implications of the transition process from products to services", Journal of Business and Industrial Marketing, Vol. 20, No. 2, pp. 70-78.

Greenstein, S. (2010). Digitalization and value creation. IEEE Micro 30(4)4-5

Håkansson, H., Networks as mechanism to develop resources, In: Beije, P., Groenewegen, J. and O. Nuys (Eds.), Networking in Dutch industries, Leuven/Apeldoorn: Garant/Siswo, 1993, pp. 207-223

Håkansson, H., and Snehota, I. (1995). Developing relationships in business networks (1st ed.). London: Routledge.

Håkansson, H., Ford, D., Gadde, L. -E., Snehota, I., and Waluszewski, A. (2009). Business in networks (1st ed.). Chichester: John Wiley \& Sons.

Hedvall, K., Dubois, A. and F. Lind (2016) Analysing an activity in context: A case study of the conditions for vehicle maintenance. Industrial Marketing Management 58 (2016) 69-82

Herterich, M.M., Übernickel, F. and W. Brenner (2015) The Impact of Cyber-Physical Systems on Industrial Services in Manufacturing, Procedia CIRP 30 (2015), pp. $323-328$

Holmström, J., Partanen, J., 2014. Digital manufacturing-driven transformations of service supply chains for complex products. Supply Chain Management 19 (4), 421-430.

Hsu, C. (2007). Scaling with digital connection: Services innovation. 2007 IEEE International Conference on Systems, Man and Cybernetics. vols. 1-8. (pp. 4057-4061). New York: IEEE.

Huang, H.C., Chu, W., Wang, W.K., Strategic performance measurement and value drivers: evidence from international tourist hotels in an emerging economy. Serv. Indust. J. 27(8), 1111-1128 (2007) 
Jaakkola, E. (2011). Unraveling the practices of "productization" in professional service firms". Scandinavian Journal of Management, 27(2), 221-230.

Jaakkola, E. and T. Hakanen (2013) Value co-creation in solution networks, Industrial Marketing Management 42 (2013) 47-58

Johanson, J. and L-G. Mattsson, Inter-organizational relations in industrial systems: a network approach compared with the transaction cost approach, In: International studies of management and organization, 1987, XVII (1), pp. 34-48

Kamp, B. (2005) Formation and evolution of buyer-supplier relationships: Conceiving dynamism in actor composition of business networks, Industrial Marketing Management 34 (2005) 658-668

Kamp, B., Ochoa, A. and Diaz, J. (2016) 'Smart servitization within the context of industrial usersupplier relationships: contingencies according to a machine tool manufacturer', International Journal on Interactive Design and Manufacturing, Doi 10.1007/s12008-016-0345-0

Kindström, D., Kowalkowski, C. (2014) Service innovation in product-centric firms: a multidimensional business model perspective. J. Busin. Indust. Market. 29(2), 96-111

Kowalkowski, C., Windahl, C., Kindström, D., and Gebauer, H. (2015). What service transition? Rethinking established assumptions about manufacturers' service-led growth strategies. Industrial Marketing Management, 44(2), 59-69.

Kowalkowski, C., Gebauer, H. and R. Oliva (2017) Service growth in product firms: past, present, and future. Industrial Marketing Management, This issue.

Kuijken, B., Gemser, G. and N.M. Wijnberg (2017). Effective product-service systems: A value-based framework, Industrial Marketing Management, This issue.

Lee, J., Kao, H-A. and S. Yang (2014) Service innovation and smart analytics for Industry 4.0 and big data environment, Procedia CIRP 16 (2014), pp. $3-8$

MacDonald, E.K., Wilson, H., Martinez, V. and A. Toossi (2011) Assessing value-in-use: A conceptual framework and exploratory study, Industrial Marketing Management 40 (2011) 671-682

Lepak, D.P., Smith, K.G., Taylor, M.S., 2007. Value creation and value capture: A multilevel perspective. Academy of Management Review 32 (1), 180-194.

Mathieu, V. (2001a). Product services: From a service supporting the product to a service supporting the client. Journal of Business and Industrial Marketing, 16(1), 39-58.

Neely, A. (2008). Exploring the financial consequences of the servitization of manufacturing, Operations Management Research, vol. 1, no. 2, pp. 103-118.

Neely, A., Benedettini, O., y Visnjic, I. (2011). The servitization of manufacturing: Further evidence. In Proceedings of 18th European operations management association conference, EurOMA 11, 3-6. Cambridge, UK 
Ng, I., Parry, G., Wilde, P., McFarlane, D., Tasker, P. (2011) Complex Engineering Service Systems: Concepts and Research, Springer: London

Oliva R , Kallenberg R. (2003) Managing the transition from products to services . International Journal of Service Industry Management 14: 160 - 172.

Osterwalder, A., Pigneur, Y., and T. Clark (2010). Business model generation: A handbook for visionaries, game changers, and challengers. Hoboken, NJ: Wiley.

Parida , V., Ronnberg-Sjodin, D., Wincent, J. y Kohtamäki, M. (2014) Mastering the Transition to Product-Service Provision Insights into Business Models, Learning Activities, and Capabilities, Research-Technology Management, 57(3), pp. 44-52.

Parry, G., Tasker, P., (2014) "Value and servitization; creating complex deployed responsive services?", Strategic Change, 23 (5-6), pp.303-315 ISSN 1099-1697

Parry, G., Brax, S.A., Maull, R., Ng., I. (2016) “Visibility of consumer context: improving reverse supply with internet of things data", Supply Chain Management: An International Journal, Vol. 21 Iss: 2, pp. $228-244$

PCAST (The President's Council of Advisors on Science and Technology): Ensuring American Leadership in Advanced Manufacturing. Report to the President. Executive Office of the President (2011)

PCAST (The President's Council of Advisors on Science and Technology): Accelerating US Advanced Manufacturing. Report to the President. Executive Office of the President (2014)

Penttinen, E., and Palmer, J. (2007). Improving firm positioning through enhanced offerings and buyer-seller relationships. Industrial Marketing Management, 36(5), 552-564.

Porter, M.E. and Heppelmann, J.E. (2014). How smart, connected products are transforming competition. Harvard Business Review 92: 11-64.

Randall, W.S., Pohlen, T.L. and Hanna, J.B. (2010). Evolving a theory of performance-based logistics using insights from service dominant logic. Journal of Business Logistics, 31(2), pp. 35-61.

Reim, W., Parida, V., and Örtqvist, D. (2015). Product-Service Systems (PSS) business models and tactics-a systematic literature review. Journal of Cleaner Production, 97, 61-75

Robinson, T., Clarke-Hill, C. M., and Clarkson, R. (2002b). Differentiation through Service: A Perspective from the Commodity Chemicals Sector. The Service Industries Journal, 22(3), 149-166

Scheer, L.K., Miao, C.F., Palmatier, R.W., 2014. Dependence and interdependence in marketing relationships: Meta-analytic insights. Journal of the Academy of Marketing Science 43 (6), 1-19.

Schroeder, A., Kotlarsky, J.: Digital resources and their role in advanced service provision: a VRIN analysis". Paper presented at Spring Servitization Conference 18 - 19 May 2015, Aston Business School Birmingham UK (2015) 
Shankar, V., Berry, L. L., and Dotzel, T. (2007). Creating and managing hybrid innovations. Innovation in services. Berkeley, CA.

Spring, M., and Araujo, L. (2014). Indirect capabilities and complex performance. Implications for procurement and operations strategy. International Journal of Operations and Production Management, 34(2), 150-173.

Stabell, C.B. and Fjeldstad, $\varnothing$.D. (1998). Configuring value for competitive advantage: on chains, shops, and networks. Strategic management journal, pp.413-437.

Storbacka, K. (2011). A solution business model: Capabilities and management practices for integrated solutions. Industrial Marketing Management, 40: 699-711.

Story, V.M., Raddats, C., Burton, J., Zolkiewski, J. and T. Baines (2017). Capabilities for advanced services: A multi-actor perspective, Industrial Marketing Management, This issue.

Teece, D. J. (2010). 'Business models, business strategy and innovation', Long range planning, 43, pp. 172-194

Tukker, A. (2004). Eight types of product-service systems: Eight ways to sustainability? Experiences from SusProNet. Business Strategy and the Environment, 13 (4) 246-260.

Tuli, K. R., Kohli, A. K., and Bharadwaj, S. G. (2007). Rethinking customer solutions: From product bundles to relational processes. Journal of Marketing, 71(3), 1-17.

Ulaga, W., Reinartz, W.J.: Hybrid offerings: how manufacturing firms combine goods and services successfully. J. Market. 75, 5-23 (2011)

Ulaga, W., and Loveland, J. M. (2014). Transitioning from product to service-led growth in manufacturing firms: Emergent challenges in selecting and managing the industrial sales force. Industrial Marketing Management, 43(1), 113-125.

Vargo, S. and R. Lusch (2004). Evolving to a new dominant logic for marketing, Journal of Marketing, 68 (January), pp. 1-17.

Vargo, S. and R. Lusch (2008). From good to service(s): Divergences and convergences of logics, Industrial Marketing Management, 37 (3), pp. 254-259 .

Vargo, S. and R. Lusch (2008). Service-dominant logic: Continuing the evolution, Journal of the Academy of Marketing Science, 36 (1), 1-10.

Vargo, S., and R. Lusch (2011). It's all B2B...and beyond: Toward a systems perspective of the market, Industrial Marketing Management, 40, pp. 181-187

Vandermerwe S, Rada J. (1988). Servitization of Business: Adding Value by Adding Services, European Management Journal 6 (4): 314-324.

Vendrell-Herrero, F., Bustinza, O., Parry, G. and N. Georgantzis (2017) Servitization, digitization and supply chain interdependency. Industrial Marketing Management, This issue 
Williamson, O.E., Markets and hierarchies: analysis and antitrust implications, New York, 1975

Williamson, O.E., The economic institutions of capitalism, New York, 1985 